\title{
sciendo
}

CIVIL AND ENVIRONMENTAL ENGINEERING REPORTS

E-ISSN 2450-8594

CEER 2021; 31 (1): 0172-0181

DOI: $10.2478 /$ ceer-2021-0012

Original Research Article

\section{ASSESMENT OF THE IMPACT OF HABITAT CONDITIONS AND LAND USE ON THE FLORISTIC DIVERSITY OF SELECTED RUSH COMMUNITIES}

\author{
Mieczysław GRZELAK ${ }^{1}$, Eliza GAWEŁ ${ }^{2}$, Leszek MAJCHRZAK ${ }^{3}$ \\ ${ }^{1}$ Department of Grassland and Natural Landscape Sciences, Poznań University of Life \\ Sciences, Poznań, Poland \\ ${ }^{2}$ Institute of Soil Science and Plant Cultivation - State Research Institute, Puławy, \\ Poland \\ ${ }^{3}$ Department of Agronomy, Poznań University of Life Sciences, Poznań, Poland
}

\begin{abstract}
This study concerned the assessment of the effect of various habitat conditions and land use on the habitat diversity of rush communities classified as Phragmitetea. The investigations were conducted in the years 2015-2019 in an area particularly interesting in terms of its nature value and abundant in localities of diverse plant communities, located in ecological areas of permanent grassland in the river valleys of the Noteć Leniwa and the Notec Bystra, as well as the interlevee floodplain of the Warta in the area of Rakowo. The study area covered 228 ha. Soil moisture content resulting from the habitat mosaic and intensity of land use had a significant effect on the formation of rush communities, their richness and floristic diversity as well as nature and agricultural value. Most communities of nature value were characterised by a mediocre economic value and low fodder value (FVS ranging from 1.1 to 6.9 ), while some were barren lands. The calculated floristic diversity index ( $\left.\mathrm{H}^{\prime}\right)$ varied and ranged from 1.9 to 3.5, while the harvested dry matter yields ranged from 2.7 to 16.6 tha $^{-1}$.

The aim of this study was to assess the effect of habitat conditions and land use on the formation and diversity of rush communities in the Noteć and the Warta river valleys.
\end{abstract}

\footnotetext{
${ }^{1}$ Corresponding author: Department of Agronomy, Poznań University of Life Sciences, ul. Dojazd 11,60-632 Poznań, Poland, e-mail: leszek.majchrzak@up.poznan.pl
} 
Keywords: rush communities, habitat conditions, floristic diversity, fodder value, yield

\section{INTRODUCTION}

Grasses and herbs are components of economically valuable plant communities found in river valleys. They play an important and advantageous role in the fodder production process as well as nature and landscape protection, while being indispensable for biodiversity. Their species richness depends on the habitat mosaic [14], soil moisture content, trophic level and land use [10]. Among the many habitat factors water plays the primary role, as it influences not only soil processes and yields, but also fodder and nature value, it affects the diversity of meadow habitats and thus the plant species composition $[4,11]$.

Some plant communities due to their excessive soil moisture content are considered to be barren lands, despite their relatively satisfactory economic value. However, they serve many advantageous functions in the natural environment and provide living and breeding grounds for numerous animal species [3, 22], particularly avifauna. In the opinion of some authors, meadow and pasture plant communities are efficient carbon sinks $[2,17,19]$. Thanks to their high degree of naturalness they are characterised by considerable esthetic and landscape value. Diversity of species found in viable associations is of significant practical importance, thanks to which large numbers of grasses, sedges, legumes and herbs in meadow or pasture swards have a positive effect on the quality of hay and products of its processing. Moreover, such a diversity of the species composition facilitates optimal habitat utilisation by meadow and pasture communities. Any changes in their floristic composition related with their depletion or the presence of common species result in the deterioration of their nature value [20]. The causative factors may include both environmental conditions, particularly land use or its absence [12]. Habitat conditions also determine the selection of land use type and its intensity [7]. Rapidly progressing transformations due to human activity, primarily drainage systems, as well as droughts may within a relatively short period of time lead to the complete disappearance of valuable plant communities, rare and endangered either in the Wielkopolska region or on the national scale [23].

Thanks to the knowledge and appropriate utilisation of plants as indicators of changes in habitat conditions it is possible to rapidly hinder adverse changes in the habitat, which are aggravated by inappropriate land use and fertilisation.

\section{MATERIAL AND METHODS}

Floristic studies were conducted in the years 2015-2019 in ecological areas of permanent grassland in the Noteć Leniwa and the Noteć Bystra river valley (the 
Wielkopolskie province, the Białośliwie and Trzcianka communes) and in Rakowo (the Lubuskie province, the Skwierzyna commune). The study area covered 228 ha. Floristic analysis was conducted applying the classical BraunBlanquet method [1]. The distinguished syntaxa were identified and classified to the phytosociological system according to Matuszkiewicz [13]. Selected rush communities were subjected to ecological evaluation, specifying species richness, floristic diversity as well as nature value based on the number of species, the Shannon-Wiener H' floristic diversity index [18] and the application of the method proposed by Oświt [15]. Habitat conditions including moisture content $(\mathrm{F})$, soil reaction $(\mathrm{R})$ and soil nitrogen abundance $(\mathrm{N})$ were evaluated using the index numbers according to Ellenberg [5]. The fodder value was assessed based on dry matter yields and fodder value score (FVS) according to Filipek [6].

Moreover, habitat moisture content was indicated by the calculated mean moisture status index numbers for a given plant community. For this purpose the phytoindication method according to Klapp, as modified by Oświt [16] was applied and they were expressed in moisture content index numbers (Lw).

\section{RESULT AND DISCUSSION}

The identified plant communities varied in their nature value as well as their economic and fodder value, which resulted most frequently from the habitat mosaic, variable moisture content and land use. They are of high nature value, natural or semi-natural character [12], forming spatial systems typical of respective plant landscapes. This is primarily vegetation of meadows and areas not utilised agriculturally in floodplain areas, frequently permanently waterlogged, typical to valleys of large rivers, as described e.g. by Grzelak and Bocian [9]. The distinguished associations are common in Poland and they are represented by expansive phytocenoses of canary grass rushes (Phalaridetum arundinaceae) and manna grass rushes (Glycerietum maximae), sedge rushes (Caricetum gracilis, C. acutiformis, C. ripariae and C. elataeae) and reed beds with aquatic plants as well as very wet localities (Phragmitetum australis, and Typhetum latifoliae, Typhetum angustifoliae, Scirpetum lacustris and Equisetum fluviatile) (Table 1).

Analyses of the number of species found in the identified communities showed the highest number of species in the Phalaridetum arundinaceae association (34), while it was lowest in the syntaxa belonging to the Typhatae (cattail) family: Typhetum latifoliae (4) and Typhetum angustifoliae (6). The share of the dominant was highest in those associations. In five associations the presence of legumes was not recorded (Table 1). In the sedge and rush group the highest share was recorded for a hydrophyte belonging to the Cyperaceae family Scirpetum lacustris (78.9\%), while it was lowest in the Typhetum latifoliae association - as 
little as $1.2 \%$. Herbs and weeds are a group of plants found in all the associations, with the highest share recorded in Caricetum elatae (48.4\%) followed by Phragmitetum australis (14.6\%).

Table 1. Floristic diversity of distinguished rush communities

\begin{tabular}{|c|c|c|c|c|c|c|c|c|}
\hline \multirow[b]{2}{*}{$\begin{array}{c}\text { Ecosystem } \\
\text { type }\end{array}$} & \multirow[b]{2}{*}{$\begin{array}{l}\text { Ecosystem } \\
\text { subtype }\end{array}$} & \multirow[b]{2}{*}{$\begin{array}{c}\text { Plant } \\
\text { community } \\
\text { (basic } \\
\text { typological unit) }\end{array}$} & \multirow[b]{2}{*}{$\begin{array}{c}\text { Number } \\
\text { of } \\
\text { speciecies }\end{array}$} & \multicolumn{5}{|c|}{ Percentage share of the species } \\
\hline & & & & Grasses & $\begin{array}{c}\text { Share of } \\
\text { dominant }\end{array}$ & Leguminous & $\begin{array}{c}\text { Sedges, } \\
\text { rushes and } \\
\text { horsetails }\end{array}$ & $\begin{array}{c}\text { Herbs } \\
\text { and weeds }\end{array}$ \\
\hline \multirow{5}{*}{$\begin{array}{l}\text { Reed } \\
\text { beds }\end{array}$} & \begin{tabular}{|l|} 
Common \\
reed beds
\end{tabular} & \begin{tabular}{|l|} 
Pragmitetum \\
australis
\end{tabular} & 15 & 79.2 & 79.2 & - & 7.9 & 12.9 \\
\hline & \multirow{4}{*}{$\begin{array}{l}\text { other reed } \\
\text { beds }\end{array}$} & \begin{tabular}{|l|}
$\begin{array}{l}\text { Typhetum } \\
\text { angustifoliae }\end{array}$ \\
\end{tabular} & 4 & 4.3 & 90.1 & - & 1.2 & 4.4 \\
\hline & & \begin{tabular}{|l|} 
Typhetum \\
latifoliae
\end{tabular} & 5 & 4.9 & 88.7 & - & 2.8 & 3.6 \\
\hline & & \begin{tabular}{|l|} 
Scirpetum \\
lacustris
\end{tabular} & 18 & 10.4 & 78.9 & - & 0.6 & 10.1 \\
\hline & & $\begin{array}{l}\text { Equisetum } \\
\text { fluviatile } \\
\end{array}$ & 9 & 9.6 & 77.2 & - & 2.7 & 10.5 \\
\hline \multirow{6}{*}{$\begin{array}{c}\text { Large } \\
\text { sedge and } \\
\text { grass } \\
\text { beds of } \\
\text { fluvial } \\
\text { wetlands }\end{array}$} & \multirow{2}{*}{\begin{tabular}{|l|} 
Manna \\
reed and \\
reed \\
canary \\
grass \\
beds \\
\end{tabular}} & $\begin{array}{l}\text { Glycerietum } \\
\text { maximae }\end{array}$ & 23 & 86.8 & 69.4 & 1.2 & 6.2 & 5.8 \\
\hline & & \begin{tabular}{|l} 
Phalaridetum \\
arundinaceae
\end{tabular} & 34 & 75.9 & 70.1 & 1.1 & 8.2 & 14.8 \\
\hline & \multirow{2}{*}{$\begin{array}{l}\text { Reed } \\
\text { rushes of } \\
\text { marginal } \\
\text { lakes }\end{array}$} & $\begin{array}{l}\text { Caricetum } \\
\text { elatae }\end{array}$ & 16 & 1.8 & 38.9 & - & 49.8 & 48.4 \\
\hline & & $\begin{array}{l}\text { Caricetum } \\
\text { ripariae }\end{array}$ & 14 & 19.2 & 52.3 & 0.6 & 68.8 & 11.4 \\
\hline & \multirow{2}{*}{\begin{tabular}{|l|} 
Sedge \\
rushes of \\
inundated \\
meadows
\end{tabular}} & $\begin{array}{l}\text { Caricetum } \\
\text { gracilis }\end{array}$ & 18 & 13.1 & 70.6 & 1.4 & 76.6 & 8.9 \\
\hline & & $\begin{array}{l}\text { Caricetum } \\
\text { acutiformis }\end{array}$ & 8 & 11.2 & 64.1 & - & 68.9 & 19.9 \\
\hline
\end{tabular}

The moisture status of the discussed plant communities, measured based on the plant indicators using the phytoindication method, indicated their considerable moisture contents, as shown by the calculated mean moisture status index number (l.w) for individual associations (Table 2) ranging from strongly moist (Phragmitetum australis $-1 \mathrm{wp}=7.6$ to swampy (Glycerietum maximae $-1 \mathrm{wp}=$ 9.2), or even aquatic (Typhetum latifoliae $-1 \mathrm{wp}=9.4$ and Typhetum angustifoliae $-\operatorname{lwp}=9.3$ ).

Habitat conditions of the identified communities were assessed according to Ellenberg [5] based on 3 soil factors: (F- moisture content, N- nitrogen abundance, 
R- - acidity) (Table 2). In terms of the moisture status index $F$ the communities may be divided into 3 groups. The first group comprises plants of moist and wet habitats (Phragmitetum australis, Scirpetum lacustris, Equisetum fluviatilis, Phalaridetum arundinaceae). The second group is characterised by the very moist status. They are swamp associations, periodically dried (Caricetum acutiformis, Glycerietum maximae, Caricetum gracilis). The third group is composed of aquatic communities (Typhetum latifoliae, Typhetum angustifoliae).

Table 2. Evaluation of habitat conditions according to Ellenberg [1992]

\begin{tabular}{|c|c|c|c|c|c|}
\hline \multirow{2}{*}{$\begin{array}{c}\text { Plant } \\
\text { community }\end{array}$} & \multirow{2}{*}{$\begin{array}{c}\text { Mean } \\
\text { humidity } \\
(\text { l.w. })^{1}\end{array}$} & \multirow{2}{*}{ Humidity sites } & \multicolumn{3}{|c|}{$\begin{array}{l}\text { Evaluation according } \\
\text { Ellenberga Ellenberg }\end{array}$} \\
\hline & & & $\mathbf{F}$ & $\mathbf{R}$ & $\mathbf{N}$ \\
\hline $\begin{array}{l}\text { Phragmitetum } \\
\text { australis }\end{array}$ & 7.6 & strongly moist & 8.5 & 7.9 & 5.4 \\
\hline $\begin{array}{l}\text { Typhetum } \\
\text { angustifoliae }\end{array}$ & 9.3 & aquatic & 8.8 & 6.8 & 5.8 \\
\hline $\begin{array}{l}\text { Typhetum } \\
\text { latifoliae }\end{array}$ & 9.4 & aguatic & 8.8 & 6.8 & 5.8 \\
\hline $\begin{array}{l}\text { Scirpetum } \\
\text { lacustris }\end{array}$ & 8.2 & wet & 7.7 & 4.8 & 5.5 \\
\hline $\begin{array}{l}\text { Equisetum } \\
\text { fluviatilis }\end{array}$ & 7.8 & wet & 7.7 & 4.7 & 5.4 \\
\hline $\begin{array}{l}\text { Glycerietum } \\
\text { maximae }\end{array}$ & 9.2 & $\begin{array}{c}\text { swampy, } \\
\text { occasionally drying }\end{array}$ & 8.5 & 7.8 & 5.6 \\
\hline $\begin{array}{l}\text { Phalaridetum } \\
\text { arundinaceae }\end{array}$ & 8.8 & $\begin{array}{l}\text { strongly moist and } \\
\text { wet }\end{array}$ & 7.8 & 6.9 & 5.4 \\
\hline $\begin{array}{l}\text { Caricetum } \\
\text { elatae }\end{array}$ & 7.8 & wet & 7.7 & 4.8 & 5.5 \\
\hline $\begin{array}{l}\text { Caricetum } \\
\text { ripariae }\end{array}$ & 8.8 & drying & 9.1 & 6.8 & 4.1 \\
\hline $\begin{array}{l}\text { Caricetum } \\
\text { gracilis }\end{array}$ & 8.1 & occasionally drying & 7.7 & 6.1 & 4.6 \\
\hline $\begin{array}{l}\text { Caricetum } \\
\text { acutiformis }\end{array}$ & 8.2 & drying & 8.5 & 6.0 & 4.8 \\
\hline
\end{tabular}

Explanations: $\mathrm{F}$ - moisture index, $\mathrm{R}$ - soil reaction index, $\mathrm{N}$ - soil of nitrogen content in soil. Moisture content numbers are referred to in this study as: 1.w. $\left(\mathrm{MCN}^{1}\right)$

The analysed communities varied in terms of their nature value (Table 3). A total of 5 communities with medium and moderate nature value were distinguished, with the mean index values of 2.7-3.4 and habitat value classes V and VI. Also in 5 communities a high and very high nature value was reported, with a mean index 
value of $3.5-4.2$ and habitat quality classes VII(C) and VIII. Most of these communities are semi-natural or natural, characterised by a richness of flora and fauna, as e.g. the marsh horsetail community (Equisetum fluviatile), as it was earlier observed also by Żukowski and Jackowiak [24]. Certain rush communities form relatively monotonous aggregations of one species, as e.g. the community with Phalaris arundinacea [8]. They also include communities of a relatively little diversified structure with hydrophilous vegetation with aquatic and rush species, but also communities composed of numerous species. Values of the floristic diversity index fell within the range of $\mathrm{H}^{\prime}=1.9-3.6$. Comparable values of the index for certain segetal communities were reported by Trąba and ZiemińskaSmyk [21] in the shelter belt of the Roztocze National Park $\left(\mathrm{H}^{\prime}=2.2-2.9\right)$.

Table. 3. Nature values of the identified plants communities

\begin{tabular}{|c|c|c|c|c|}
\hline Plant community & $\begin{array}{c}\text { Mean habitat } \\
\text { quality index } \\
\text { number }\end{array}$ & Natural qualities & Habitat quality class & $\mathrm{H}^{1}$ \\
\hline $\begin{array}{l}\text { Phragmitetum } \\
\text { australis }\end{array}$ & 4.2 & High & VI (B) & 3.6 \\
\hline $\begin{array}{l}\text { Typhetum } \\
\text { angustifoliae }\end{array}$ & 4.3 & Very high & VIII (C) & 3.5 \\
\hline $\begin{array}{l}\text { Typhetum } \\
\text { latifoliae }\end{array}$ & 3.9 & Very high & VII (C) & 3.3 \\
\hline $\begin{array}{l}\text { Scirpetum } \\
\text { lacustris }\end{array}$ & 2.8 & $\begin{array}{l}\text { Moderately } \\
\text { medium }\end{array}$ & IV (B) & 2.4 \\
\hline $\begin{array}{l}\text { Equisetum } \\
\text { fluviatilis }\end{array}$ & 3.1 & $\begin{array}{c}\text { Moderately } \\
\text { high }\end{array}$ & VI $(\mathrm{C}$ & 1.9 \\
\hline $\begin{array}{l}\text { Glycerietum } \\
\text { maximae }\end{array}$ & 4.4 & Exceptional & IX (D) & 2.9 \\
\hline $\begin{array}{l}\text { Phalaridetum } \\
\text { arundinaceae }\end{array}$ & 3.4 & $\begin{array}{l}\text { Moderately } \\
\text { high }\end{array}$ & VI (B & 3.4 \\
\hline Caricetum elatae & 3.5 & high & VIII (C) & 2.7 \\
\hline $\begin{array}{l}\text { Caricetum } \\
\text { ripariae }\end{array}$ & 3.1 & $\begin{array}{l}\text { Moderately } \\
\text { high }\end{array}$ & VIII (C) & 2.6 \\
\hline $\begin{array}{l}\text { Caricetum } \\
\text { gracilis }\end{array}$ & 3.8 & $\begin{array}{c}\text { Moderately } \\
\text { high }\end{array}$ & VII C & 3.3 \\
\hline $\begin{array}{l}\text { Caricetum } \\
\text { acutiformis }\end{array}$ & 3.7 & high & VII (C) & 2.9 \\
\hline
\end{tabular}

1 - Shannon-Wiener floristic diversity index

Table 4 presents yields and fodder value of the discussed plant communities. The above-mentioned plant associations exhibit considerable diversity both in terms of yielding and the fodder value score. The plant 
association providing the highest yields of dry matter was Phragmitetum australis $\left(8.2-16.5\right.$ tha $\left.^{-1}\right)$, while the lowest yield was obtained from the community Equisetum fluviatile $\left(2.7-3.6\right.$ tha $\left.^{-1}\right)$. Yields of biomass from sedge rushes varied and ranged from 3.9 to $6.6 \mathrm{tha}^{-1}$. In the case of aquatic and wet rushes due to technical causes no yields were recorded.

In terms of the sward value only in the Phalaridetum arundinaceae association it is good and amounted to Lwu $=6.9$, while in all the others the calculated Lwu value indicated that they were poor communities. The above-mentioned plant communities differed also in terms of the number of species, including also those of economic value.

Table. 4. Moisture content variability of syntaxonomic units and yield and fodder value scores of identified plant communities

\begin{tabular}{|c|c|c|c|c|}
\hline $\begin{array}{l}\text { Ecosystem } \\
\text { type }\end{array}$ & Plant community & $\begin{array}{c}\text { Yield } \\
\left(\mathrm{t} \mathrm{sm}-\mathrm{DM} \mathrm{ha}{ }^{-1}\right)\end{array}$ & $\begin{array}{l}\mathrm{Lwu}^{2} \\
\mathrm{Uvn}\end{array}$ & $\begin{array}{c}\text { Value of } \\
\text { sward }\end{array}$ \\
\hline \multirow{5}{*}{ Reed beds } & $\begin{array}{l}\text { Phragmitetum } \\
\text { australis }\end{array}$ & $8.2-16.5$ & 1.1 & poor \\
\hline & $\begin{array}{l}\text { Typhetum } \\
\text { angustifoliae }\end{array}$ & - & 2.1 & poor \\
\hline & Typhetum latifoliae & - & 2.2 & poor \\
\hline & Scirpetum lacustris & - & 2.5 & poor \\
\hline & Equisetum fluviatile & $2.7-3.6$ & 1.2 & poor \\
\hline \multirow{6}{*}{$\begin{array}{l}\text { Large } \\
\text { sedge and } \\
\text { grass beds } \\
\text { of fluvial } \\
\text { wetlands }\end{array}$} & $\begin{array}{l}\text { Glycerietum } \\
\text { maximae }\end{array}$ & $6.8-9.8$ & 2.8 & poor \\
\hline & $\begin{array}{l}\text { Phalaridetum } \\
\text { arundinaceae }\end{array}$ & $7.4-12.2$ & 6.9 & good \\
\hline & Caricetum elatae & $3.9-5.2$ & 1.6 & poor \\
\hline & Caricetum ripariae & $4.2-5.5$ & 1.8 & poor \\
\hline & Caricetum gracilis & $4.1-6.6$ & 1.8 & poor \\
\hline & $\begin{array}{l}\text { Caricetum } \\
\text { acutiformis }\end{array}$ & $5.3-5.7$ & 1.7 & poor \\
\hline
\end{tabular}

2 - Moisture content numbers are referred to in this study as: 1.w. (MCN*) 


\section{CONCLUSION}

1. Grassland and rush communities found in the Noteć Leniwa and the Notec Bystra valley and in the valley of the Warta represent diverse nature value, forming valuable ecosystems of high landscape value.

2. The formation of grassland communities, their richness and floristic diversity, nature and agricultural value are influenced first of all by their moisture content, resulting from the mosaic character of these habitats and intensity of their use.

3. As a result of excessive moisture content of most habitats in the analysed area most of the communities of high nature value have mediocre economic and fodder value, while some of them are barren.

4. Economic and fodder value of the analysed meadows depends mainly on the conditions and varied use, as indicated by the produced yields of dry matter (from 2.7 to 12.2 t.ha $^{-1}$ ) and FVS ranging from 1.1 to 6.9.

\section{REFERENCES}

1. Braun-Blanquet, J. Pflanzensoziologie. 2 Aufl. Springer, Wien. 1951, pp. 631.

2. Chang, J, Ciais, P, Viovy, N, Vuichard, N, Sultan, B and Soussana, JF 2015. The greenhouse gas balance of European grasslands. Glob. Chang. Biol. 21, 3748-3761.

3. Chodkiewicz, T, Kuczyński, L, Sikora, A, Chylarecki, P, Neubauer, G, Ławicki, $€$ and/ Stawarczyk, T 2015. Population estimates of breeding birds in Poland in 2008-2012. Ornis Polonica, 56, 149-189.

4. Dembek, W 2002. Dylematy związane z ochroną terenów otwartych w dolinach rzecznych. In: Aktualne problemy ochrony mokradet. Red. W. Dembek. Woda-Środowisko-Obszary Wiejskie. Rozpr. Nauk. Monogr., 4, 8292.

5. Ellenberg, H 1992. Zeigerwerte von Pflanzen in Mitteleuropa. Scripta Geobot, 18, 5-258.

6. Filipek, M 1973. Project of evaluation of medow and pasture habitat based on fodder value score inde. (Projekt kwalifikacji siedlisk łąkowych i pastwiskowych na podstawie liczb wartości użytkowej. Post. Nauk Rol., 4, 59-68.

7. Grzegorczyk, S 2016. The role of grasslands ecosystems in environmental management. (Użytkowanie ekosystemów trawiastych a kształtowanie 
środowiska). Zesz. Probl. Post. Nauk. Rol., 586, 19-32.

8. Grzelak, M 2004. Phytosociological diversification against the habitat background in some river valleys of Great Poland. (Zróżnicowanie fitosocjologiczne szuwaru mozgowego Phalaridetum arundinaceae (Koch 1926 n.n.) Libb. 1931 na tle warunków siedliskowych w wybranych dolinach rzecznych Wielkopolski). Rocz. AR Pozn. Rozpr. Nauk., 354, pp. 138.

9. Grzelak, M and Bocian, T 2006. Geobotanical diversity of semi-natural communities of the „Bystra” Notec valley and their role in the landscape. (Zróżnicowanie geobotaniczne zbiorowisk seminaturalnych doliny Noteci Bystrej oraz ich rola w krajobrazie). Ann. UMCS. Sect. E, 61, 257-266.

10. Grzelak, M, Gaweł, E, Janyszek, M, Wrońska-Pilarek, D, Janyszek, S, Murawski, M and Knioła, A 2017. Nature and fodder value of grass-sedge communities in the Noteć valley in the Natura 2000 area. Journal of Research and Applications in Agricultural Engineering, 62(3), 135-141.

11. Humphreys, MW, O'Donovan, G and Sheehy-Skeffington, M 2014. Comparing synthetic and natural grasslands for agricultural production and ecosystem service. Grass. Sci. in Eur., 19, 215-229.

12. Klarzyńska, A and Kryszak, A 2015. Floristic diversity of extensively used fresh meadows (6510) in the Wielki Łęg Obrzański Complex. Acta Agrobot., $\mathbf{6 8}(2), 115-123$.

13. Matuszkiewicz, W 2018. Guidebook for determination of plant communities in Poland. (Przewodnik do oznaczania zbiorowisk roślinnych Polski). Warszawa. PWN, 537.

14. Oprŝal, Z, Sarapatka, B and Kladivo, P 2013. Land use changes and their relationships to selected landscape parameters in theree cadastral areas in Moravia (Czech Republik), Moravian Geographical Reports, 21(1), 41-50.

15. Oświt, J 1992. Identification of humidity conditions in medow sites using vegetation indices. (Identyfikacja warunków wilgotnościowych w siedliskach łąkowych za pomocą wskaźników roślinnych [metoda fitoindykacji]). W: Hydrogeniczne siedliska wilgotnościowe. Bibl. Wiad. IMUZ, 79, 39-67.

16. Oświt, J 2000. Metoda przyrodniczej waloryzacji mokradeł i wyniki jej zastosowania w wybranych obiektach. Falenty. IMUZ, 3-32.

17. Skuodiene, R and Tomchuk, D 2014. Effects of biomass of perennial grasses and legumes on soil carbon. Grassland Science in Europe, 19, 388-390.

18. Shannon, CE and Wiener N 1949. The mathematical theory of communication. Urbana, IL, University of Illinois Press.

19. Soussana, JF, Klumpp, K and Ehrhardt, F 2014. The role of grassland in mitigating climate change. Grassland Science in Europe, 19, 75-87.

20. Trąba, Cz, Wolański, P and Oklejewicz, K 2006. Floristic diversity of selected nonforest plant communities in the San river valley. (Różnorodność florystyczna wybranych zbiorowisk nieleśnych doliny Sanu). Annales UMCS 
ASSESMENT OF THE IMPACT OF HABITAT CONDITIONS AND LAND USE ON THE 181 FLORISTIC DIVERSITY OF SELECTED RUSH COMMUNITIES

Sec. E, 61, 267-275.

21. Trąba, $\mathrm{Cz}$ and Ziemińska-Smyk, M 2006. Floristic diversity of weed communities in the root crops of the Roztocze National Park buffer zone. (Różnorodność florystyczna zbiorowisk chwastów w uprawach roślin okopowych otuliny Roztoczańskiego Parku Narodowego). Pam. Put., 14, 195-206.

22. WallisDeVries, MF and van Swaay, CAM 2009. Grasslands as habitats for butterflies in Europe. In: Veen P, Jefferson R, de Smidt J, van der Straaten J, editors. Grasslands in Europe of high nature value. Zeist: KNNV Publishing.

23. Zarzycki, J and Korzeniak, J 2013. Medows in the Polish Carphatians present state changes and preservation prospects. (Łąki w polskich Karpatach - stan aktualny, zmiany i możliwości ich zachowania). Roczn. Bieszcz., 21, 18-34.

24. Żukowski, W and Jackowiak, B 1995. Ginące i zagrożone rośliny Pomorza Zachodniego i Wielkopolski. Prace Zakładu Taksonomii Roślin UAM w Poznaniu, 3, 1-141. Bogucki Wyd. Nauk. Poznań.

Editor received the manuscript: 17.11.2020 